\title{
Relationship between seedbank and above-ground botanical composition during spring
}

\author{
K.N. Tozer ${ }^{1}$, G.M. Barker ${ }^{2}$, C.A. Cameron ${ }^{1}$ and T.K. James ${ }^{1}$ \\ ${ }^{1}$ AgResearch, Ruakura Research Centre, Hamilton 3240, New Zealand \\ ${ }^{2}$ Landcare Research, Private Bag 3127, Hamilton 3240, New Zealand \\ Corresponding author: katherine.tozer@agresearch.co.nz
}

\begin{abstract}
Poor pasture persistence and ingress of weedy species are major concerns for farmers. The seedbank gives an indication of what weedy species may establish in pastures and compete with sown species. It was hypothesised that the above-ground composition reflects the seedbank. The seedbank was sampled and botanical assessments were undertaken during October-November 2009 in Northland, Waikato, Taranaki and North Canterbury. Above-ground botanical composition did not reflect the weed seedbank composition in any of the regions assessed. While cover of grasses was greater than legumes and herbs above-ground, weedy herbs were most dominant in the seedbank, followed by grasses then legumes. There was no emergence of sown grass from the seedbank, highlighting the lack of a persistent sown grass seedbank, which may contribute to poor pasture persistence.
\end{abstract}

Keywords weed seedbank, pasture persistence, seedling recruitment.

\section{INTRODUCTION}

Poor persistence of sown species and ingress of undesirable species is of increasing concern for pastoral farmers. Lack of persistence entails the mortality of sown species as well as their inability to replace themselves through vegetative spread or seedling recruitment in the field. A contributing factor may be lack of a persistent seedbank of naturally reseeding sown species and a persistent seedbank of weedy species. The impact of the weed seedbank on persistence would depend on the enterprise, as plants in more extensively managed pastures often have greater opportunity to set seed in comparison to intensively managed systems. Weed seedlings compete strongly with sown species, especially if sown species are preferentially grazed. Over time, this would increase the proportion of weedy species in a pasture, particularly given poor recruitment of sown species.

Research in Australian and American pastures has shown that seedling recruitment by natural reseeding of species such as phalaris (Phalaris aquatica), ryegrass (Lolium perenne) and cocksfoot (Dactylis glomerata) can be poor (e.g. Sanderson et al. 2007). In New Zealand dry hill country results were variable. Hume \& Barker (1991) observed 283 ryegrass seedlings $/ \mathrm{m}^{2}$ and $144 / \mathrm{m}^{2}$ prairie grass seedlings, but few seedlings of cocksfoot, tall fescue and phalaris. Ryegrass seedling establishment in a Waikato dairy pasture was higher, although it depended on the management regime (L'Huillier \& Aislabie 1987). In addition to poor recruitment, 
ryegrass does not have a persistent seedbank, nearly all seeds germinate in the autumn following their production (Bell 1995). In contrast, species with a persistent seedbank can germinate at a later date with favourable conditions, such as the death of an existing plant and creation of a canopy gap. Seedbanks also ensure against 'false autumn breaks', when a proportion of seeds germinate but plants do not establish.

To assess the potential impact of the seedbank in spring on pasture persistence, the botanical composition of the above-ground plant and below-ground seedbank communities was compared in four New Zealand regions. The aim was to provide an indication of which sown and unsown species have a persistent seedbank to facilitate self-replacement and the consequences of this for pasture persistence. The null hypothesis was that the above-ground botanical composition reflected the seedbank.

\section{METHOD}

Botanical composition of above-ground pasture communities was assessed in spring 2009 for 30 paddocks in each of four regions: Waikato and Taranaki (dairy); and Northland and North Canterbury (sheep, beef, deer). On each farm, 2 to 5 paddocks were randomly chosen to provide a sample of pastures with ages ranging from 2 to 20 years. Criteria for paddock selection included: knowledge of the original sown mix, no irrigation and no undersowing since renovation. Pastures varied in the mix with which they were sown. Most pastures were sown with a ryegrass base. Other grasses were: tall fescue (Schedonorus arundinaceus), cocksfoot, prairie grass and grazing bromes (Bromus spp.), timothy (Phleum pratense) and phalaris. Sown legumes were white clover (Trifolium repens), red clover (T. pratense), sub clover (T. subterraneum), lucerne (Medicago sativa) and lotus (Lotus spp.), while sown herbs were chicory (Cichorium intybus) and narrow-leaved plantain (Plantago lanceolata). Plant species were identified and their percent cover visually estimated in four, $2 \mathrm{~m} \times 2 \mathrm{~m}$ randomly placed quadrats in each paddock.

Eighteen of the 30 paddocks were randomly chosen for soil seedbank assessment. Fifteen soil cores $(2.5 \mathrm{~cm}$ diameter and $7 \mathrm{~cm}$ deep) were collected from each paddock in each region while undertaking the above botanical assessments. To estimate composition of the soil seedbank, $500 \mathrm{~g}$ soil from each paddock was sieved and placed in a $2 \mathrm{~cm}$ layer on trays in a glasshouse. Trays were maintained at ambient temperatures and watered as required to keep the soil moistened to field capacity. Most seedling emergence from the seedbank occurs within the first week using this seedling enumeration method (Rahman et al. 2004). Emerged seedlings were identified then removed. This was done for up to 4 weeks, by which time no more seedling emergence occurred.

Data were analysed using Residual Maximum Likelihood (REML) in GenStat, 11th edition (GenStat Committee 2008) to produce means. REML allowed for the unbalanced design arising from different numbers of paddocks ( 2 to 5 ) per farm. Species cover and seedling emergence data (Tables 2 and 4) were angular transformed to normalise the variance.

\section{RESULTS}

\section{Above-ground botanical composition}

Grass cover was greater than legume and herb cover in all regions (Table 1). Ryegrass was the most dominant grass: its cover was greater than $37 \%$ in all regions and it was present at nearly all sites in each region (Table 2).

Tall fescue and cocksfoot were less frequently sown. Average tall fescue cover in paddocks in which it was sown was $43 \%$ in Northland (5 paddocks), $17 \%$ in Waikato (14 paddocks) and $61 \%$ in Taranaki (5 paddocks). In Canterbury, average cocksfoot cover was $17 \%$, in the 14 paddocks in which it was sown. These average covers are higher than those shown in Table 2, where species covers are averaged over all paddocks assessed. White clover was the most dominant legume and was present at nearly all sites. Red clover was only present in three of the 16 dryland pastures in Canterbury in which it was sown, with an average cover of $7 \%$. The most dominant herbs were buttercup (Ranunculus spp.) and narrow-leaved plantain, the latter 
Table 1 Average cover (\%) of grasses, legumes and herbs for 30 pastures in four regions of New Zealand assessed in spring 2009.

\begin{tabular}{lccccc}
\hline & Northland & Waikato & Taranaki & Canterbury & SED \\
\hline Grass & 68 & 58 & 69 & 60 & 6.5 \\
Legume & 16 & 24 & 14 & 31 & 5.5 \\
Herb & 12 & 13 & 14 & 5 & 3.2 \\
\hline
\end{tabular}

Table 2 Average cover (\%) of the five most dominant species in 30 pastures for each of four regions of New Zealand assessed in spring 2009 ( \pm SE). Cover data are back-transformed means. Data in parentheses are percent of sites at which they were present.

\begin{tabular}{|c|c|c|c|c|}
\hline Species & Northland & Waikato & Taranaki & Canterbury \\
\hline \multicolumn{5}{|l|}{ Grasses and rushes } \\
\hline Ryegrass & $44 \pm 8 \quad(94)$ & $42 \pm 4(100)$ & $58 \pm 9(100)$ & $37 \pm 9(97)$ \\
\hline Poa spp. & $6 \pm 2 \quad(94)$ & $6 \pm 2 \quad(98)$ & & \\
\hline Tall fescue & $1 \pm 1 \quad(19)$ & $1 \pm 1 \quad(23)$ & $2 \pm 2 \quad(34)$ & \\
\hline Cocksfoot & & & & $2 \pm 2(50)$ \\
\hline \multicolumn{5}{|l|}{ Legumes } \\
\hline White clover & $11 \pm 2(100)$ & $21 \pm 4(100)$ & $11 \pm 3(100)$ & $9 \pm 3(97)$ \\
\hline Subterranean clover & & & & $3 \pm 2(66)$ \\
\hline Red clover & & & & $2 \pm 3(19)$ \\
\hline \multicolumn{5}{|l|}{ Herbs } \\
\hline Narrow-leaved plantain & $4 \pm 2 \quad(66)$ & & $2 \pm 1 \quad(50)$ & \\
\hline Buttercup & & $1 \pm 1(71)$ & $2 \pm 2 \quad(41)$ & \\
\hline
\end{tabular}

comprising predominantly of a sown commercial cultivar (Table 2). Average, sown herb (chicory and/or plantain) cover in paddocks where they were sown comprised 13\% (Northland), 4\% (Waikato), 6\% (Taranaki) and 5\% (Canterbury).

\section{Seedling emergence from the seedbank}

Above-ground composition did not reflect the composition of emerged seedlings from the seedbank. Herb emergence was greater than that of grasses and legumes in all regions, except Waikato where there was high grass emergence. Legume emergence was $12 \%$ or less in all regions (Table 3).

While the five most dominant species from the seedbank gave rise to $42 \%$ (Taranaki), $58 \%$ (Waikato) and 44\% (Canterbury) of total seedling emergence, they only accounted for $37 \%$ in Northland (Table 4). No sown grasses emerged from the seedbank in any region. Rough meadow

Table 3 Total emergence (\%) of grass, legume and herb seedlings from the seedbank sampled from 18 pastures in four regions of New Zealand in spring 2009.

\begin{tabular}{lccccc}
\hline & Northland & Waikato & Taranaki & Canterbury & SED \\
\hline Grass & 37 & 51 & 25 & 16 & 12.0 \\
Legume & 10 & 3 & 2 & 12 & 3.3 \\
Herb & 52 & 46 & 72 & 73 & 12.5 \\
\hline
\end{tabular}


Table 4 Average contribution (\%) of the five most dominant species to total seedling emergence from soil sampled from 18 pastures in four regions of New Zealand in spring 2009 ( \pm SE). Seedling emergence data are back-transformed means. Data in parentheses are the percent of sites at which they were present.

\begin{tabular}{|c|c|c|c|c|}
\hline Species & Northland & Waikato & Taranaki & Canterbury \\
\hline \multicolumn{5}{|l|}{ Grasses and rushes } \\
\hline Rough meadow grass & $20 \pm 6(83)$ & $5 \pm 2(83)$ & $6 \pm 2(78)$ & $8 \pm 4(67)$ \\
\hline Smooth witch grass & & $2 \pm 2(39)$ & & \\
\hline Summer grass & & $29 \pm 10$ & $4 \pm 4(44)$ & \\
\hline Toad rush & $4 \pm 2(44)$ & & & $4 \pm 3(33)$ \\
\hline \multicolumn{5}{|l|}{ Legumes } \\
\hline White clover & $7 \pm 2(78)$ & & & $4 \pm 2(56)$ \\
\hline \multicolumn{5}{|l|}{ Herbs } \\
\hline Amaranthus & & $4 \pm 3(56)$ & & \\
\hline Black nightshade & $3 \pm 2(44)$ & & & \\
\hline Broad-leaved plantain & $3 \pm 3$ & $18 \pm 4(94)$ & $18 \pm 7(83)$ & \\
\hline Fathen & & & & $21 \pm 13(67)$ \\
\hline Shepherd's purse & & & & $7 \pm 8$ \\
\hline Twincress & & & $11 \pm 6(72)$ & \\
\hline Willow weed & & & $3 \pm 3(44)$ & \\
\hline
\end{tabular}

grass (Poa trivialis), toad rush (Juncus bufonius), summer grass (Digitaria sanguinalis) and smooth witchgrass (Panicum dichotomiflorum) were the most dominant grasses / rushes in the seedbank (Table 4).

White clover was present among seedlings emergent from $78 \%$ (Northland), $67 \%$ (Waikato), $44 \%$ (Taranaki) and 56\% (Canterbury) soils but was only among the five most dominant seedbank-species in Northland and Canterbury (Table 4). Lotus spp., subterranean clover and suckling clover (Trifolium dubium) emergence also occurred (data not shown). Subterranean and suckling clovers were often self-sown species.

Emerged herbs were predominantly unsown, weedy species such as amaranthus (Amaranthus spp.), black nightshade (Solanum nigrum), fathen (Chenopodium album), shepherd's purse (Capsella bursa-pastoris), twincress (Lepidium didymus), willowweed (Persicaria maculosa) and broad-leaved plantain (Plantago major) (Table 4). Chicory emergence from pastures in which it had been sown was low and only occurred in Waikato and Northland (data not shown). Commercial plantain emergence was also low. However, it occurred more frequently than chicory in paddocks in which it had been sown and was present in $50 \%$ of Northland paddocks (data not shown).

\section{DISCUSSION}

Contrary to the null hypothesis, the aboveground botanical composition did not reflect the seedbank in spring. While pastures assessed were dominated by sown perennial grasses in all regions, only one sown perennial grass seedling emerged from the seedbank of one of the 72 paddocks assessed. The lack of ryegrass emergence in spring highlights the lack of a persistent ryegrass seedbank; most ryegrass seeds germinate rapidly the autumn after they are produced and have little dormancy (L'Huillier \& Aislabie 1987). Furthermore, it is unlikely that ryegrass recruitment is adequate to maintain ryegrass populations in intensively managed pastures. Thom et al. (1998) found a significant reduction 
in ryegrass dry matter production over 3 years in Waikato dairy pastures. Perennial grass mortality can be high in grazed pastures due to pulling, dung deposition, urine scorch and trampling. This decline in sown grasses and the ingress of weedy annual grasses was observed particularly after the severe Waikato drought of 2008 in ryegrass-based dairy pastures (Tozer et al. 2009). The lack of a persistent ryegrass seedbank could contribute to this decline. For example, there may be no persistent ryegrass seed to colonise bare ground after false autumn breaks. White clover showed more promise than sown grasses in being self-replacing due to its persistent seedbank, although its seedling emergence was much less than that of herbaceous species present in the seedbank. In contrast, many weedy species such as Poa spp., which possess a persistent seedbank (Howe \& Chancellor 1983), were often dominant in this study and are therefore better able to take advantage of bare ground created in pastures at different times during the year.

Weedy herb species were generally the most frequent seedlings emerging from the seedbank, although they were not the most frequent species above-ground. While germination and emergence of weedy herbs can be prolific in pastures, seedling mortality may often be high. Only a small proportion of weed seeds produced survive and establish in grazed pastures where competition for resources from other species can be severe (e.g. Edwards et al. 2005). However, given the high numbers of herbaceous weed seeds in the seedbank in spring, it is possible that overgrazed and moisture-stressed pastures that lack vigour, or suffer mortality in sown species, would be vulnerable to rapid ingress of herbaceous weeds. This may be the case during summer droughts, when overgrazing occurs during summer when feed is in short supply, or when pastures are pugged during winter. In contrast, pastures with a high content of competitive sown species would be much less susceptible to weed ingress.

Broad-leaved plantain was observed in all regions, demonstrating its ability to inhabit a range of different soil types and survive a wide range of climatic conditions. Commercial narrow- leaved plantain emerged from the seedbank where it was sown, but also was frequently present in soil from paddocks where it was not sown. Farmers interviewed in association with this research commented that commercial plantain seeds survived passage through livestock and germinated in the dung, which would contribute to its spread into other paddocks, even under intensive grazing regimes. This may also occur for unsown, wild-type plantain.

Intensive grazing practices may be contributing to poor seedling recruitment of many of the sown species and ingress of the weedy species. High stocking rates and intensive grazing can reduce seed production, increase mortality of sown species and create canopy gaps that promote establishment of weedy species. Some farmers interviewed intentionally made hay in some paddocks to increase seed-set and selfreplacement of sown species. However, while haymaking can increase seed-set of desirable species, it may also increase seed-set and recruitment of weeds. Edwards et al. (2005) observed that increased recruitment of sown species may be difficult to achieve by grazing management alone as managing pastures to promote the establishment and persistence of sown species can concurrently favour unsown, weedy species. Weeds would need to be managed so that the desirable species establish and survive.

In this study, some of the seeds in the seedbank may have remained dormant under glasshouse conditions, leading to an underestimation of potential seedling recruitment. However, seeds of many sown pasture species have little dormancy and readily germinate under favourable conditions in the first autumn after ripening (e.g. Howe \& Chancellor 1983), with little carry-over of seeds into spring. Additionally, not all winter-active species had set seed when pastures were sampled in spring 2009 in this study. Therefore, spring sampling may have led to an underestimation of seedling recruitment of some sown species, although results are in accord with other published literature that report poor seedling recruitment and the lack of a persistent seedbank of sown species. Autumn sampling may 
give a better indication of winter-active species present in the seedbank.

Both summer- and winter-active species emerged in this study, indicating that the temperature and moisture regime in the glasshouse was adequate for germination of a range of species within the 4-week assessment period. However, emergence of winter-active species such as Poa spp. may have been greater if seedling emergence was assessed for a longer period (Rahman et al. 2004). Nonetheless, it was generally weedy species that emerged, highlighting both the persistent nature of the weed seedbank and its large size and the lack of a persistent seedbank of sown species, in all regions assessed. Clearly, pastures are vulnerable to weed ingress once sown plants become stressed and unable to compete against the potentially large numbers of weed seedlings that can emerge from the seedbank. This emphasises the importance of management practices such as lax grazing or spelling in some paddocks to allow both seedset of sown species and good canopy cover to exclude weed recruitment (L'Huillier \& Aislabie 1987; Hume \& Barker 1991). This is currently practiced in some North Canterbury deer and sheep farms when establishing a prairie grass-based pasture. However, this would be less appropriate in intensive dairy pastures, as intensive grazing aims to maintain pasture quality and prevent seedset. In this case, management practices that improve the vegetative spread of sown species would be more useful.

\section{ACKNOWLEDGEMENTS}

We gratefully acknowledge the Sustainable Farming Fund and MAF SLMACC for funding this research. Thanks also Nadine Loick, Derrick Wilson, Mike Trolove, Yuki Fukuda and Shona Lamoureaux for valuable assistance with field work.

\section{REFERENCES}

Bell CC 1995. Subtropical seed-bank of a Bay of Plenty dairy farm. Proceedings of the New Zealand Grassland Association 57: 59-61.

Edwards GR, Hay MJM, Brock JL 2005. Seedling recruitment dynamics of forage and weed species under continuous and rotational sheep grazing in a temperate New Zealand pasture. Grass and Forage Science 60: 186199.

Howe CD, Chancellor RJ 1983. Factors affecting the viable seed content of soils beneath lowland pastures. Journal of Applied Ecology 20: 915-922.

Hume DE, Barker DJ 1991. Natural reseeding of five grass species in summer dry hill country. Proceedings of the New Zealand Grassland Association 53: 97-104.

L'Huillier PJ, Aislabie DW 1987. Natural reseeding in perennial ryegrass/white clover dairy pastures. Proceedings of the New Zealand Grassland Association 49: 111-115.

Rahman A, James TK, Grbavac N, Mellsop J 1995. Evaluation of two methods for enumerating the soil weed seedbank. Proceedings of the 48th New Zealand Plant Protection Conference: 175-180.

Sanderson MA, Goslee SC, Klement KD, Soder KJ 2007. Soil seed bank composition in pastures of diverse mixtures of temperate forages. Agronomy Journal 99: 1514-1520.

Thom ER, Waugh CD, McCabe RJ 1998. Growth and persistence of perennial and hybrid ryegrasses when grazed by dairy cows in the central Waikato region of New Zealand. New Zealand Journal of Agricultural Research 41: 477-486.

Tozer KN, James TK, Cameron CA 2009. Changes in Setaria pumila abundance after drought: implications for pasture management. New Zealand Plant Protection 61: 121-126. 